\title{
AGRICULTURE 4.0 AND IMPROVING COMPETITIVENESS OF THE DOMESTIC AGRO-FOOD SECTOR
}

\author{
Cariša Bešić ${ }^{1}$, Mihalj Bakator ${ }^{2}$, Dejan Đorđević3 ${ }^{3}$ Dragan Ćoćkalo ${ }^{4}$
}

*Corresponding author E-mail: mihalj.bakator@uns.ac.rs

A R T I C L E I N F O
Review Article
Received: 05 March 2020
Accepted: 19 April 2021
doi:10.5937/ekoPolj2102531B
UDC 631:[339.137:338.439

Keywords:

competitiveness, agriculture 4.0, standardization, ICT, agro-food sector

JEL: D24, O13, Q16, Q18

\section{A B S T R A C T}

The domestic agro-food sector has an important role in economic development and in overall GDP growth. The concept of Agriculture 4.0 that integrates the use of information-communication technologies presents a direction in which the domestic agriculture sector should focus. Additionally, besides conducting business within the frameworks of Agriculture 4.0, the standardization of processes in the agro-food sector can also contribute to achieving competitiveness on the globalized market. In this paper the importance and number of ISO standards are investigated. In addition, factors and indicators that characterize Agriculture 4.0 are analysed. Based on the collected and analysed data, a unified competitiveness factor (UCF) is calculated for the period from 2017 to 2020. The UCF provides and overview on the potential competitiveness of the domestic agro-food sector. The paper contributes to the existing body of literature as it managed to provide a strong basis for future research in this domain.

(C) 2021 EA. All rights reserved.

1 Cariša Bešić, Ph.D., Full Professor, University of Kragujevac, Faculty of technical science Čačak, 32000 Čačak, Svetog Save 65, Republic of Serbia. Phone: +381 603699696 , E-mail: carisa.besic@sbb.rs, ORCID ID (https://orcid.org/0000-0001-5370-5328)

2 Mihalj Bakator, Ph.D., Teaching Assistant, University of Novi Sad, Technical faculty "Mihajlo Pupin" in Zrenjanin, 23000 Zrenjanin, Đure Đakovića bb, Republic of Serbia. Phone: +38161 18061 69, E-mail: mihalj.bakator@uns.ac.rs, ORCID ID (http://orcid. org/000-0001-8540-2460)

3 Dejan Đorđević, Ph.D., Full Professor, University of Novi Sad, Technical faculty "Mihajlo Pupin" in Zrenjanin, 23000 Zrenjanin, Đure Đakovića bb, Republic of Serbia. Phone: +381 6280197 26, E-mail: dejan.djordjevic@tfzr.rs, ORCID ID (https://orcid.org/0000-00019453-9207)

4 Dragan Ćoćkalo, Ph.D., Full Professor, University of Novi Sad, Technical faculty "Mihajlo Pupin" in Zrenjanin, 23000 Zrenjanin, Đure Đakovića bb, Republic of Serbia. Phone: +381 6280197 41, E-mail: dragan.cockalo@tfzr.rs, ORCID ID (http://orcid.org/0000-00032085-5420) 


\section{Introduction}

In this research the digitalization of agriculture - Agriculture 4.0, the necessity of standardization, the importance of highly finalized and processed agricultural products are analysed. Data from FAO, ISO and other organizations was collected and analysed in order to derive significant insight into the competitiveness of the domestic agro-food sector. Additionally, potential future trends are discussed, which are accompanied by suggestions and guidelines for improving the Serbian agricultural sector in accordance with the concepts that are part of Agriculture 4.0. This explorative research is significant as it addresses crucial competitiveness factors in the domestic agro-food sector in the context of Agriculture 4.0, which can be viewed as a concept within framework of Industry 4.0. In addition, it takes into consideration recent studies and the newest available data, thus it contributes to the existing body of literature.

This paper consists of four sections (excluding the Introduction and Conclusion sections). The first section provides details on the materials and methods. More precisely, the data sources and the approach to data analysis are described. In the second section the importance of ISO standards and ICTs are noted and additional data on ISO standards is provided. In the third section the concept of agriculture 4.0 is highlighted and the crucial role of highly processed, finalized products in competitiveness is highlighted. Additionally, a unified competitiveness factor (UCF) is calculated with the goal to identify the future potential competitiveness of the domestic agro-food sector. From here, graphs for predicting future trends are presented. In the fourth section the results are briefly discussed, suggestions and guidelines for improving competitiveness of the domestic agro-food sector are proposed.

\section{Competitiveness, ICT and the importance of standardization}

Traditional approaches to agriculture and the overall food industry are no longer viable due to increasing food demands. More precisely, by 2050 the demand for food will rise by up to $70 \%$ (De Clercq et al., 2018). This increase in demand further increases production. However, this production has to be improved and revolutionized in order to reduce water and energy consumption, and to achieve higher quality foods, higher yields with less pesticides and fertilizers. Further, the concept of the fourth evolution in farming technology - Agriculture 4.0 arises and it aims at increasing productivity, adapting to climate change laws and requirements, avoiding waste and effectively allocating resources (Zhai, et al., 2020). It can be argued that Agriculture 4.0 includes modern information-communication technologies (ICTs), which are the cornerstone of the fourth industrial revolution - Industry 4.0. Next, in order to achieve the aims and strategic goals that are outlined in the Agriculture 4.0 approach, it is necessary to digitalize farming procedures and supply chains in order to reduce the consumption of water, fertilizers, and pesticides.

The digitalization of the agro-food sector includes the implementation and application of robots, moisture sensors, temperature sensors, GPS technology, and aerial images 
(De Clercq et al., 2018). Furthermore, the domestic agro-food sector is characterized with the process of standardization of agro-products with the goal to increase regional competitiveness (Ikram et al., 2020). However, the majority of standards that are applied in the Balkans, more precisely in Serbia, are mainly mandatory standards, which don't contribute significantly to the competitiveness of the domestic agro-foods sector (Ćoćkalo et al., 2019). The lack of national competitiveness additionally affects the competitiveness of the domestic agro-food sector. Low productivity, minimal standardization, and old farming equipment significantly contribute to the inadequate competitive ability of the Serbian agricultural sector (Bešić et al., 2014).

Furthermore, the modern business environment is characterized by constant changes on the globalized market. These changes are increasing and intensifying over time and present a challenges for enterprises in all industrial sectors (Đorđević, et al., 2016). In order to stay relevant on the market, enterprises have to meet customers' demands and expectations, and to provide high, consistent levels of product and service quality in order to increase customer satisfaction (Popović, \& Miletić, 2016; Milojević et al., 2020). When it comes to overall competitiveness of the domestic economy, according to the latest rankings noted in the Global Competitiveness Report 2019 (WEF, 2019), Serbia is ranked 72nd (out of 141). In the same report, neighbouring countries and countries in the region are ranked as follows: Albania 81st; Austria 21st; Bosnia and Herzegovina 92nd; Bulgaria 49th; Croatia 63rd; Greece 59th; Hungary 47th; Montenegro 73rd; North Macedonia 82nd; and Slovenia 35th (WEF, 2019). It is evident that Serbia has room for improvement regarding its competitiveness ranking. ICT adoption, the financial system, and the institutions have to be improved in order to increase national competitiveness. Significant investments into to the ICT sector and the application of ICT in other sectors is crucial for economic growth (Domazet et al., 2018).

ICT adoption in the agriculture sector is a prerequisite for Agriculture 4.0, which brings improvements when it comes to agricultural development (Simonović, Ćurčić, 2018). Further, standardization of business operations can improve productivity, increase product and service quality, and increase the competitive advantage on the market (Miletić et al., 2020). The importance of standards is present in the agriculture sector, as the increase of ISO standards can improve product quality and increase competitiveness when it comes to export of agricultural goods (Aničić, Paraušić, 2020). Next, in Table 1., the number of ISO standards in all sectors for 2018 and 2019, for Serbia and neighbouring countries is presented.

Table 1. Number of ISO standards in Serbia and region (all sectors)

\begin{tabular}{|l|c|c|c|c|c|c|c|c|c|c|}
\hline \multicolumn{1}{|c|}{ Country } & \multicolumn{2}{|c|}{ ISO 9001 } & \multicolumn{2}{c|}{ ISO 14001 } & \multicolumn{2}{c|}{$\begin{array}{c}\text { ISO/IEC } \\
\mathbf{2 7 0 0 1}\end{array}$} & \multicolumn{2}{c|}{ ISO 50001 } & \multicolumn{2}{c|}{$\begin{array}{c}\text { ISO/IEC } \\
\mathbf{2 0 0 0 0}\end{array}$} \\
\hline & 2018 & 2019 & 2018 & 2019 & 2018 & 2019 & 2018 & 2019 & 2018 & 2019 \\
\hline Albania & 214 & 363 & 144 & 151 & 19 & 33 & 4 & 8 & 3 & 1 \\
\hline Austria & 3282 & 3325 & 1079 & 1052 & 157 & 81 & 237 & 236 & 9 & $/$ \\
\hline $\begin{array}{l}\text { Bosnia and } \\
\text { Herzegovina }\end{array}$ & 1346 & 935 & 291 & 742 & 24 & 31 & 12 & 11 & $/$ & $/$ \\
\hline
\end{tabular}




\begin{tabular}{|l|r|r|r|r|r|c|c|c|c|c|}
\hline \multicolumn{1}{|c|}{ Country } & \multicolumn{2}{|c|}{ ISO 9001 } & \multicolumn{2}{c|}{ ISO $\mathbf{1 4 0 0 1}$} & \multicolumn{2}{c|}{$\begin{array}{c}\text { ISO/IEC } \\
\mathbf{2 7 0 0 1}\end{array}$} & \multicolumn{2}{c|}{ ISO 50001 } & \multicolumn{2}{c|}{$\begin{array}{c}\text { ISO/IEC } \\
\text { 20000 }\end{array}$} \\
\hline Bulgaria & 5943 & 6278 & 1946 & 1993 & 339 & 367 & 181 & 252 & 92 & 95 \\
\hline Croatia & 2343 & 2715 & 1027 & 1182 & 138 & 190 & 136 & 194 & 10 & 15 \\
\hline Greece & 6165 & 6570 & 1415 & 1542 & 240 & 336 & 81 & 109 & 13 & 17 \\
\hline Hungary & 6658 & 7107 & 2391 & 2547 & 484 & 554 & 613 & 472 & 30 & 26 \\
\hline Montenegro & 137 & 163 & 63 & 91 & 11 & 11 & $/$ & $/$ & $/$ & $/$ \\
\hline North Macedonia & 436 & 502 & 306 & 292 & 33 & 30 & 6 & 3 & 25 & $/$ \\
\hline Romania & 9299 & 9506 & 4553 & 4658 & 585 & 654 & 58 & 57 & 51 & 42 \\
\hline Serbia & 2427 & 2707 & 1169 & 1275 & 223 & 258 & 73 & 87 & 22 & 10 \\
\hline Slovenia & 1710 & 1761 & 432 & 468 & 80 & 31 & 30 & 27 & $/$ & $/$ \\
\hline
\end{tabular}

Source: ISO, 2019

According to Table 1., there is an increase of ISO standards in Serbia from 2018 to 2019. The largest number of standards is noted in Romania, followed by Greece, and Bulgaria on the third place by the number of ISO standards.

Overall, the number of standards in Serbia is not adequate, improvement is necessary, however, there is a solid base when it comes to the current number of ISO certificates. Next, in Table 2. the number of ISO standards in the agriculture sector for 2018 and 2019, for Serbia and neighbouring countries is presented.

Table 2. Number of ISO standards in Serbia and region (agriculture sector)

\begin{tabular}{|l|c|c|c|c|c|c|c|c|c|c|c|}
\hline \multicolumn{1}{|c|}{ Country } & \multicolumn{2}{|c|}{ ISO 9001 } & \multicolumn{2}{c|}{ ISO 14001 } & \multicolumn{2}{c|}{$\begin{array}{c}\text { ISO/IEC } \\
\mathbf{2 7 0 0 1}\end{array}$} & \multicolumn{2}{c|}{ ISO 50001 } & \multicolumn{2}{c|}{$\begin{array}{c}\text { ISO/IEC } \\
\mathbf{2 0 0 0 0}\end{array}$} & SUM \\
\hline & 2018 & 2019 & 2018 & 2019 & 2018 & 2019 & 2018 & 2019 & 2018 & 2019 & 2019 \\
\hline Albania & 2 & 2 & 1 & 2 & $/$ & $/$ & $/$ & $/$ & $/$ & $/$ & 7 \\
\hline Austria & 2 & 2 & $/$ & 1 & $/$ & $/$ & $/$ & $/$ & & $/$ & 4 \\
\hline $\begin{array}{l}\text { Bosnia and } \\
\text { Herzegovina }\end{array}$ & 5 & 4 & 3 & 3 & $/$ & $/$ & $/$ & $/$ & $/$ & $/$ & 15 \\
\hline Bulgaria & 236 & 315 & 42 & 38 & 11 & 9 & $/$ & $/$ & $/$ & $/$ & 631 \\
\hline Croatia & 22 & 28 & 12 & 13 & $/$ & $/$ & $/$ & $/$ & $/$ & $/$ & 75 \\
\hline Greece & 33 & 41 & 4 & 4 & $/$ & $/$ & $/$ & $/$ & $/$ & $/$ & 82 \\
\hline Hungary & 35 & 56 & 5 & 10 & $/$ & $/$ & & $/$ & $/$ & $/$ & 106 \\
\hline Montenegro & 1 & 1 & 1 & 1 & $/$ & $/$ & $/$ & $/$ & $/$ & $/$ & 4 \\
\hline $\begin{array}{l}\text { North } \\
\text { Macedonia }\end{array}$ & $/$ & 2 & $/$ & 3 & $/$ & $/$ & $/$ & $/$ & $/$ & $/$ & 5 \\
\hline Romania & 20 & 41 & 11 & 23 & $/$ & $/$ & $/$ & $/$ & $/$ & $/$ & 95 \\
\hline Serbia & 19 & 18 & 6 & 4 & $/$ & $/$ & 1 & 1 & $/$ & $/$ & 49 \\
\hline Slovenia & 3 & 3 & $/$ & $/$ & $/$ & $/$ & $/$ & $/$ & $/$ & $/$ & 6 \\
\hline
\end{tabular}

Source: ISO, 2019

Based on the data in Table 2., Serbia has 49 ISO standards in the agriculture sector, and this number should be higher, considering the importance of the agriculture sector from the aspect of national economic growth (Tomić, Radanov, 2020). Therefore, it can be argued that this number is inadequate, and there should be an increase in number 
of standards in the agriculture sector. Further, the ISO 22000:2018 standard for food and safety management systems that defines the requirements for any organization in the food chain, plays a significant role in the agriculture sector as well as sectors that are directly or indirectly connected to the agriculture sector. The ISO 22000 standard can implemented and used by every participant in food supply chains. Therefore, in the context of competitiveness of the domestic agro-food sector, ISO 22000 provides a cornerstone of food safety improvement, food quality improvement, reducing costs in supply chains, and increasing customer trust (Chen et al., 2019). In Table 3. the number of ISO standards for 2018 and 2019 (latest data) in Serbia and neighboring countries is presented.

Table 3. Number of ISO 22000 standards in Serbia and other countries

\begin{tabular}{|l|c|c|c|c|c|c|c|c|c|c|c|c|}
\hline Country/year & AL & AU & BH & BU & CRO & GR & HU & MN & NM & RO & SRB & SLO \\
\hline 2018 & 29 & 72 & 30 & 324 & 59 & 1912 & 127 & 13 & 61 & 653 & 216 & 12 \\
\hline 2019 & 12 & 82 & 20 & 310 & 58 & 2024 & 126 & 12 & 54 & 639 & 195 & 13 \\
\hline Legend: \\
AL - Albania; AU - Austria; BH - Bosnia and Herzegovina; BU - Bulgaria; CRO - Croatia; \\
GR - Greece; HU - Hungary; MN - Montenegro; NM - North Macedonia; RO - Romania; SRB - \\
Serbia; SLO - Slovenia \\
\hline
\end{tabular}

Source: ISO, 2019

The data in Table 3. indicates that. compared to neighbouring countries, Serbia has a moderate number of ISO 22000 standards, thus it can be argued that there is a basis for further development in the agro-food sector. In the next section, Agriculture 4.0, the necessity for highly processed agricultural products, and the potential competitiveness of the domestic agro-foods sector are addressed.

\section{Data and methods}

The globalization of markets and the changes that are brought on by the fourth industrial revolution - Industry 4.0 significantly affect the process of achieving and maintaining competitiveness on the market, regardless of industry (Bakator et al., 2019). This lack of competitiveness of domestic enterprises is evident in the agro-food sector as well.

The research was carried out for over a month where spreadsheets were collected, and data extracted, categorized for comparison and analysis. Data on the number of ISO standards was obtained via the ISO database with the latest data (ISO, 2019). Further, data regarding the agro-food sector was obtained from the Food and Agriculture Organization of the United Nations (FAO, 2021). Next, data on the implementation and application of information-communication technologies (ICT) in domestic enterprises was obtained from the Statistical Office of the Republic of Serbia (RSZ, 2021). Additionally, information and data was obtained and analysed from other studies in this domain.

Data analysis included data categorization, deduction, and qualitative correlation analysis. In addition, graphs presenting future potential trends are modelled. In addition, 
several metrics in the agricultural sector (water consumption, production, industry valued GDP, agriculture valued GDP etc.). In addition, data regarding the digitalization of domestic enterprises was obtained and analysed. Through categorization and tabular comparison of data it was managed to develop comprehensive tables that present the competitiveness of the domestic agro-food sector. Further, graphs indicating trends are modelled in order to provide an overview on the strategic potential of the domestic agro-food sector in the future.

The obtained results, presented in these tables and graphs, are further examined in the discussion section. Here, suggestions and guidelines for improving the domestic agrofood sector within the frameworks of Agriculture 4.0 are proposed. The suggestions and guidelines are based on the obtained results. More precisely, the current situation regarding the competitiveness of the domestic agro-food sector, and future potential trends are the cornerstones of the noted suggestions and guidelines.

\section{Agriculture 4.0 and the potential of the domestic agriculture sector}

Digitalized agricultural production, and the effects of ICT application in farming are mainly positive as they contribute to productivity, water use efficiency, and less pesticide use (Klerkx et al., 2019). However, the use of advanced technologies such as artificial intelligence systems, robotics, Big Data Analytics, and Internet of Things should be strategically implemented, as these changes have societal effects besides economic effects (Rose, Chilvers, 2018). As agricultural production is faces challenges when it comes to yield, pesticide use, and sustainable development, the use of technologies that are within the framework of Agriculture 4.0 slowly becomes an imperative (Ozdogan et al., 2017). Besides the noted necessity for modern ICT use in the agro-food sector, it is necessary to process and finalize agricultural products to the highest degree, as such products bring the most value when exported (Đurić et al., 2017). This further indicates the necessity for higher number of standards (Wilcock, Boys, 2017).

Standards in the agro-food sector can be implemented from various aspects, including products, ICT, and environment sustainability. More precisely, the implementation of the ISO 14001 standard provides a solid basis for sustainable development in the agrofood sector, where the environment is not uncontrollably exploited, but rather strategic actions are introduced in in order to comply with the ISO 14001 standard, which further increases environmental protection and preservation (Carrillo-Labella et al., 2020; Zhao et al., 2020). Standardization of finalized products positively affects exports of agricultural products (Kim, 2021).

It can be argued that Agriculture 4.0 goes along and relies on modern ICT adoption, standardization, and highly finalized products that have higher value compared to raw or semi-processed products. In Table 4., the agriculture gross value added to GDP for the period of 2003 to 2017, for Serbia and neighbouring countries is presented. 
Table 4. Agriculture value added to GDP in \% (and in millions of US)

\begin{tabular}{|c|c|c|c|}
\hline Country & 2003-2007 & 2008-2012 & 2013-2017 \\
\hline Albania & $\begin{array}{l}17.15 \% \\
(1.831) \\
\end{array}$ & $\begin{array}{l}18.77 \% \\
(2.312) \\
\end{array}$ & $\begin{array}{l}19.01 \% \\
(2.476) \\
\end{array}$ \\
\hline Austria & $\begin{array}{l}1.42 \% \\
(5.505) \\
\end{array}$ & $\begin{array}{r}1.35 \% \\
(5.521) \\
\end{array}$ & $\begin{array}{l}1.20 \% \\
(5.033) \\
\end{array}$ \\
\hline $\begin{array}{l}\text { Bosnia and } \\
\text { Herzegovina }\end{array}$ & $\begin{array}{l}7.71 \% \\
(1.215) \\
\end{array}$ & $\begin{array}{l}6.14 \% \\
(1.057) \\
\end{array}$ & $\begin{array}{l}5.60 \% \\
(1.012) \\
\end{array}$ \\
\hline Bulgaria & $\begin{array}{l}4.65 \% \\
(2.066) \\
\end{array}$ & $\begin{array}{l}4.41 \% \\
(2.345) \\
\end{array}$ & $\begin{array}{l}4.04 \% \\
(2.995) \\
\end{array}$ \\
\hline Croatia & $\begin{array}{l}3.73 \% \\
(2.242) \\
\end{array}$ & $\begin{array}{l}3.34 \% \\
(1.886) \\
\end{array}$ & $\begin{array}{l}2.94 \% \\
(1.624) \\
\end{array}$ \\
\hline Greece & $\begin{array}{r}3.04 \% \\
(9.673) \\
\end{array}$ & $\begin{array}{l}3.24 \% \\
(7.954) \\
\end{array}$ & $\begin{array}{l}3.70 \% \\
(7.540) \\
\end{array}$ \\
\hline Hungary & $\begin{array}{l}3.49 \% \\
(4.887)\end{array}$ & $\begin{array}{l}3.91 \% \\
(5.012)\end{array}$ & $\begin{array}{l}3.80 \% \\
(5.374) \\
\end{array}$ \\
\hline Montenegro & $\begin{array}{l}7.23 \% \\
(266) \\
\end{array}$ & $\begin{array}{l}7.45 \% \\
(304) \\
\end{array}$ & $\begin{array}{l}6.85 \% \\
(332) \\
\end{array}$ \\
\hline North Macedonia & $\begin{array}{c}8.93 \% \\
(744) \\
\end{array}$ & $\begin{array}{c}9.11 \% \\
(887)\end{array}$ & $\begin{array}{c}7.87 \% \\
(890)\end{array}$ \\
\hline Romania & $\begin{array}{l}5.50 \% \\
(9.605) \\
\end{array}$ & $\begin{array}{l}4.67 \% \\
(8.002) \\
\end{array}$ & $\begin{array}{l}4.31 \% \\
(9.131) \\
\end{array}$ \\
\hline Serbia & $\begin{array}{l}8.28 \% \\
(3.336) \\
\end{array}$ & $\begin{array}{l}7.53 \% \\
(3.069) \\
\end{array}$ & $\begin{array}{l}6.02 \% \\
(2.656) \\
\end{array}$ \\
\hline Slovenia & $\begin{array}{l}2.05 \% \\
(983)\end{array}$ & $\begin{array}{l}1.96 \% \\
(914)\end{array}$ & $\begin{array}{l}1.85 \% \\
(899)\end{array}$ \\
\hline
\end{tabular}

Source: FAO, 2021

The Food and Agriculture Organization of the United Nations (FAO, 2021), only has data up to 2017. The Statistical Office of the Republic of Serbia has data from 2018 to 2020 , where the agriculture gross added value to GDP in 2018 was $7 \%$, in 2019 was $6.9 \%$, and in 2020 was $7.5 \%$. (RZS, 2018; RZS, 2019). It is also noted that the agriculture gross added value to GDP is an important factor that made the COVID-19 pandemic and economic crisis less impactful on the overall GDP loss in 2020 (Danas, 2020). The real growth of the agricultural sector in 2007, 2012, and 2017 was $-11.4 \%$, $15.1 \%$ and $1.6 \%$ respectively $(\mathrm{FAO}, 2021)$. The latest growth rate has to be improved as the agricultural sector is a strong cornerstone of the domestic economy (Gligorijević et al., 2020). Next, in Table 5 the percentage of agricultural water withdrawal from the total renewable water sources and irrigated agriculture water use efficiency in 2007 , 2012, and 2017 for Serbia and neighbouring countries is presented. 
Table 5. Agriculture water withdrawal as \% of total renewable water sources (and Irrigated Agriculture Water Use Efficiency (US\$ $\left./ \mathrm{m}^{3}\right)$

\begin{tabular}{|l|c|c|c|}
\hline \multicolumn{1}{|c|}{ Country } & $\mathbf{2 0 0 3 - 2 0 0 7}$ & $\mathbf{2 0 0 8 - 2 0 1 2}$ & $\mathbf{2 0 1 3 - 2 0 1 7}$ \\
\hline \multirow{2}{*}{ Albania } & 1.76 & 1.98 & 3.00 \\
& $(0.708)$ & $(1.444)$ & $(1.220)$ \\
\hline \multirow{2}{*}{ Austria } & 0.11 & 0.010 & 0.10 \\
& $(3.148)$ & $(3.484)$ & $/$ \\
\hline \multirow{2}{*}{ Bosnia and Herzegovina } & $/$ & $/$ & $/$ \\
\hline \multirow{2}{*}{ Bulgaria } & $/$ & $4.465)$ \\
\hline \multirow{2}{*}{ Croatia } & $(0.116)$ & $(0.081)$ & 3.92 \\
& 0.003 & 0.034 & $(1.124)$ \\
\hline \multirow{2}{*}{ Greece } & $(10.23)$ & 12.11 & $(1.496)$ \\
\hline \multirow{2}{*}{ Hungary } & 12.37 & $(0.387)$ & 13.22 \\
& $(0.464)$ & 0.31 & $(0.440)$ \\
\hline \multirow{2}{*}{ Montenegro } & 0.296 & $(0.651)$ & 0.499 \\
& $(0.431)$ & $(3.66)$ & $/$ \\
\multirow{2}{*}{ North Macedonia } & $/$ & 21.14 & $(45.85)$ \\
\hline \multirow{2}{*}{ Romania } & $(/)$ & $(0.169)$ & 5.14 \\
& 1.96 & 0.515 & $(0.682)$ \\
\hline \multirow{2}{*}{ Serbia } & $(1.564)$ & $(0.263)$ & 0.703 \\
& 0.518 & 0.385 & $(0.270)$ \\
\hline \multirow{2}{*}{ Slovenia } & $(0.258)$ & $0.149)$ & 0.407 \\
& 0.079 & $(6.651)$ & $(0.122)$ \\
\hline
\end{tabular}

Source: FAO, 2021

Based on the data in Table 5. it can be seen that in Serbia agriculture water withdrawal as of total renewable water sources is $0.407 \%$. This number is low compared to Greece (13.22\%), North Macedonia (5.14\%), Bulgaria (3.92\%), and Albania (3\%). In order to become competitive within the frameworks of Agriculture 4.0. it is necessary address this factor.

Next, in Table 6. the percentages of ICT application in domestic enterprises from all sectors are presented.

Table 6. Information-communication technology application in enterprises (all sectors)

\begin{tabular}{|l|c|c|c|c|}
\hline & $\mathbf{2 0 1 7}$ & $\mathbf{2 0 1 8}$ & $\mathbf{2 0 1 9}$ & $\mathbf{2 0 2 0}$ \\
\hline Internet connection in Serbian enterprises & $99.7 \%$ & $99.8 \%$ & $99.8 \%$ & $100 \%$ \\
\hline $\begin{array}{l}\text { Broadband, fast Internet connections in Serbian } \\
\text { enterprises }\end{array}$ & $98.6 \%$ & $98.8 \%$ & $97.1 \%$ & $98.4 \%$ \\
\hline Mobile Internet use in domestic enterprises & $81.9 \%$ & $75.4 \%$ & $79.1 \%$ & $77 \%$ \\
\hline Domestic enterprises that have a website & $82.6 \%$ & $82.6 \%$ & $83.6 \%$ & $84.4 \%$ \\
\hline Website has the function of online purchasing & $18.7 \%$ & $25.1 \%$ & $28.9 \%$ & $28.1 \%$ \\
\hline E-commerce & $23.8 \%$ & $26.3 \%$ & $27.5 \%$ & $27.9 \%$ \\
\hline Use of Cloud applications & $15.5 \%$ & $15.5 \%$ & $21.9 \%$ & $18.6 \%$ \\
\hline Average \% & 60.11 & 60.5 & 62.56 & 62.06 \\
\hline
\end{tabular}

Source: RZS, 2021 
Based on the data presented in Table 6., there is an increase in ICT solution implementation and application across various sectors. The lowest percentages are noted in the E-commerce sector and in the application of cloud-based solutions.

Quantification and integration of values from Tables 2., 4., 5., and 6. is conducted in order to create a unified competitiveness indicator of the domestic agro-food sector. The unified competitiveness indicator takes into consideration:

- the number of ISO standards in the domestic agriculture sector (label: ISODA);

- the agriculture value added to GDP in \% (label: GDPA);

- real growth in \% of gross value added (GVA) of the agriculture, forestry and sighing sector (label: GVAG)

- agriculture water withdrawal as \% of total renewable water sources (label: AWW);

- $\quad$ irrigated agriculture water use efficiency (US\$/m3) (label: AWUE);

- and the average potential of information-communication technology (ICT) application in domestic enterprises (label: ICTDE).

The noted indicators are chosen as these encompass several key concepts that characterize Agriculture 4.0. These concepts are standardization as a mechanism to improve international presence (export potential) (Caetano, 2017); agriculture \% of total GDP as an indicator of how agriculture affects the performance of the overall domestic economy (Aničić, et al., 2016); agriculture GVA real growth in \% as this can show what trends are present in the agriculture sector when it comes to growth; agriculture water withdrawal $\%$ of total renewable water sources present a key indicator within Agriculture 4.0, as one of the goals are to increase the use of water from renewable resources (Velasco-Muñoz et al., 2018); water use efficiency from agriculture irrigation has the same impact and importance as using water from renewable sources and together are also important factors for sustainable development (Aznar-Sánchez et al., 2018); the potential of ICT implementation and application present a driving mechanism of agriculture development as it can increase productivity, yield, and contribute to the increase of production of highly processed agricultural products that have higher market value compared to raw or half-processed goods (Mikhailushkin, 2018; Saidu, 2017).

An equation for determining the unified competitiveness factor (UCF) is introduced:

$\mathbf{U C F}=$ xisum $_{2019} /$ xmaxsum $_{2019} * 100+100 * \mathrm{GDPA}(\%)+100 * \mathrm{GVAG}(\%)+100 * \mathrm{AWW}$ $(\%)-(x \operatorname{mintabx} * 100 /$ AWUE $)+100 * \operatorname{ICTDE}(\operatorname{avg} \%)$.

Overall, based on the equation the percentages are multiplied with 100, while for water efficiency use, the lowest value from the table is multiplied with 100 and divided with the domestic values). For the ISO standards the sum values for 2019 are used (this is the latest data). Further, for ICT, as there are several factors with percentages, the average percentage is used and it is multiplied with 100 . 
The UCF is calculated for 2017, 2018. 2019 and 2020. The newest available data is used. However, as for some factors there is no available data for example 2020. In those cases, the value from previous year used.

The noted equation for calculating the UCF presents an approach that can provide some insight into future trends when it comes to Agriculture 4.0 development and competitiveness of the domestic agro-food sector. The results of the calculation for the years 2017, 2018, 2019, and 2020 are presented in Table 7.

Table 7. Unified competitiveness factor (UCF) of the domestic agro-food sector

\begin{tabular}{|l|c|c|c|c|}
\hline & $\mathbf{2 0 1 7}$ & $\mathbf{2 0 1 8}$ & $\mathbf{2 0 1 9}$ & $\mathbf{2 0 2 0}$ \\
\hline UCF for the agro-food sector & 170.57 & 197.45 & 185.91 & 186.01 \\
\hline UCF for the agro-food sector (normalized into scale of 1-100) & 86.39 & 100 & 94.15 & 94.21 \\
\hline
\end{tabular}

Source: Authors

The results in Table 7. indicate a gradual rise in competitiveness of the domestic agrofood sector. From here, the results are presented on a graph Figure 1. and future potential scenarios for the upcoming years are noted and discussed. The potential scenarios are based on the obtained and analysed data.

Figure 1. Potential competitiveness outcomes (scenarios) of the domestic agro-food sector

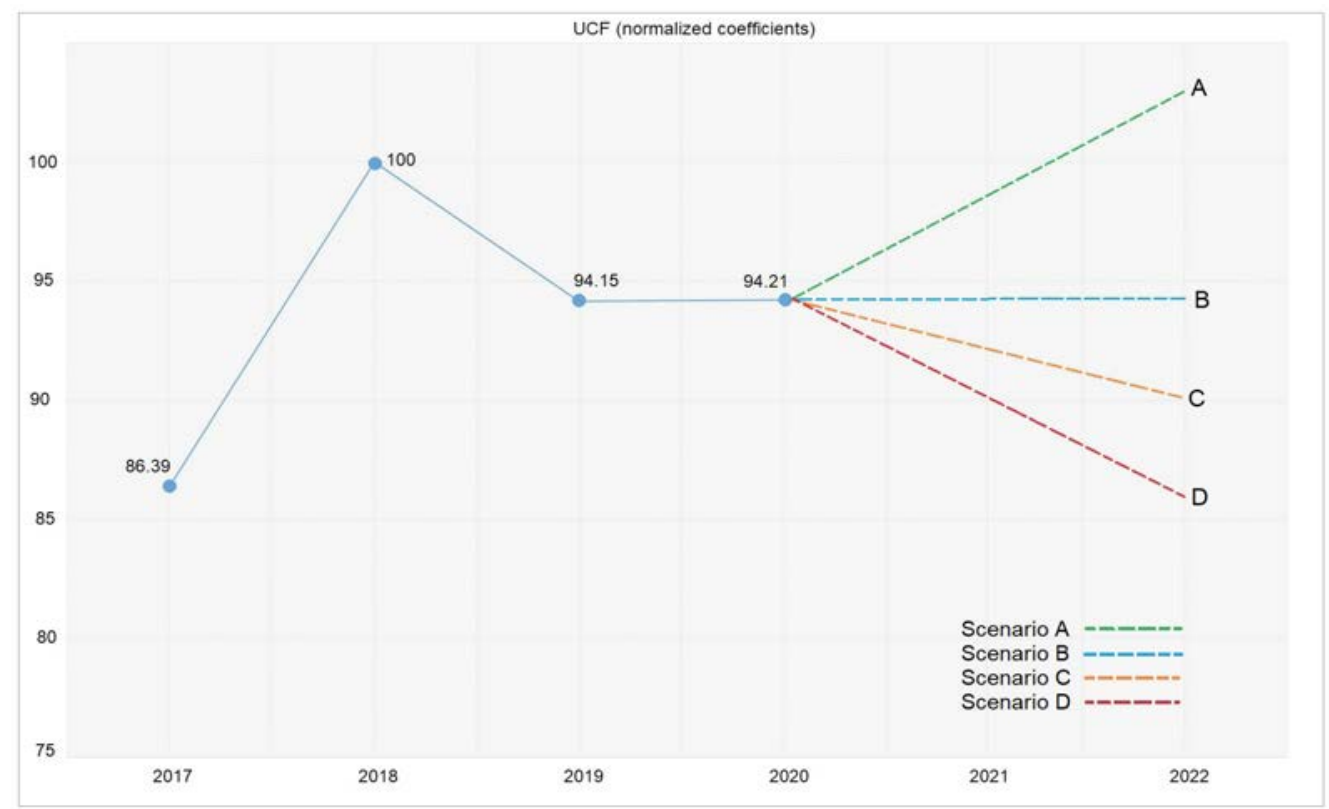

Source: Authors

Figure 1. depicts the UCF from 2017 to 2020. Additionally, four scenarios (A, B, C, and D) are noted. These scenarios represent the potential of the domestic agriculture sector in the next two years. The scenarios are derived from logical assumptions are by analysing previous trends. 
Scenario A presents an outcome where there is an increased number of ISO standards in the agriculture sector; higher water use efficiency for irrigation; higher percentages of water use from renewable water resources; higher percentage of ICT implementation and application; and a significantly higher growth of gross added value to GDP and percentage of total GDP.

In scenario B, only mild increase of the noted factors would be sufficient to maintain the current competitiveness ability of the domestic agriculture sector. Mild increase is necessary, as the market is constantly changing and competition on the market is evolving and intensifying. Next, scenario $\mathbf{C}$ is the potential outcome if there is no change and a slight decrease in the noted factors and indicators.

Finally, the least favourable competitive strength of the domestic agriculture sector is presented as scenario D. This scenario would occur if there is a significant decrease in the number of ISO standards, decrease of water efficiency use, decrease of water use from renewable water sources, as well as decrease in ICT application percentages. Due to the COVID-19 pandemic, the current business environment is dynamic and enterprises face challenges in all sectors. Therefore, if scenario A has a low probability of occurring. Scenario B is a more likely outcome of the current economic climate.

\section{Discussion}

Increasing the competitiveness of the domestic agro-food sector requires significant and systematic engagement on various levels of government. The obtained and analysed data regarding ISO standards, agro-food indicators, and ICT application provided significant insight into the current state of competitive ability of the domestic agro-food sector. With the goal to provide a concise overview of current and future potential competitiveness of the domestic agro-food sector, a unified competitiveness factor (UCF) was calculated. From here, the graph (Figure 1.) was constructed with potential future competitiveness scenarios. Based on the analysed data, and on the obtained results of the analysis the following suggestions and guidelines for improving competitiveness of the domestic agro-food sector are proposed:

- Systematically increase the number of ISO standards in the agro-food sector, but also in other industrial sectors as well. Focus should be on standards that would result in improvement of quality, ICT adoption and sustainable development.

- Increase awareness among local communities on the importance and significance of the ISO 22000 when it comes to the competitiveness of the domestic agro-food sector.

- Increase the awareness of ICT application benefits in agriculture to farmers and local communities.

- Provide adequate infrastructure for ICT solutions across various agro-food sub-sectors. This should include farmlands, semi-processing, and finalized processing of products. 
- Develop strategic plans for implementing ICTs in the agro-food sector, and provide support in the form of seminars and education of workers that would apply the ICT.

- Systematically increase the number and intensity of highly processed, finalized agricultural products. This involves creating value in products rather than exporting raw or semi-processed products.

- Develop short-term and long-term plans regarding national and local agricultural product processing with the goal to reduce the export of unprocessed (raw) products and increase the number finalized products.

- Focus on environment preservation through Agriculture 4.0 concepts, including the increase of irrigation water use efficiency, increase of water use from renewable water sources, and reduction of pesticide use.

Overall, when it comes to Agriculture 4.0 the domestic agro-food sectors requires a multisolution approach where several mechanisms are introduced with the goal to strategically and organically increase the number of ISO standards in agriculture, increase water use efficiency, reduce pesticide use; increase the percentage of finalized products in export, and to overall increase productivity, and yield in agriculture production.

This current paper contributes to the existing body of literature as it integrates important data on the domestic agro-food sector, standardization, and ICT application. This data is categorized, analysed, and used to create a significant overview on the potential competitiveness of the domestic agro-food sector.

\section{Conclusion}

Competitiveness of the domestic agro-food sector is affected by numerous factors. In this paper data regarding ISO standards, agriculture, and ICT application in enterprises is analyzed. It can be concluded that the potential competitiveness of the domestic agrofood sector relies on several indicators in these three aspects (standards, agriculture, ICT). In addition, it was noted that in order to increase competitiveness in agriculture, it is necessary to address all the "weak points" regarding product-type exports (highly processed and finalized products, instead of raw and semi processed products); agriculture (water use efficiency, growth of gross added value, organic farming and/or reduced use of pesticides); and number of standards (primarily in the agro-food sector, but in other sectors as well).

The limitation of this paper is that the research is conceptualized around obtaining and analyzing data from external databases, as there were no surveys within this research. However, the goal of the paper was to provide an overview and solid basis for future research, thus the noted limitation is not severe. For future research empirical data from farms and other agriculture-based enterprises could be collected via survey or interview. 


\section{Conflict of interests}

The authors declare no conflict of interest.

\section{References}

1. Aničić, J., \& Paraušić, V. (2020). Trends in development of Serbian agriculture after the economic crisis in 2008. Western Balkan Journal of Agricultural Economics and Rural Development, 2(2), 111-122.

2. Aničić, J., Vukotić, S., \& Krstić, S. (2016). The strategic aspects and results of agriculture development in Serbia in the transition period. Ekonomika poljoprivrede, 63(1).

3. Aznar-Sánchez, J.A., Belmonte-Ureña, L.J., Velasco-Muñoz, J.F., \& ManzanoAgugliaro, F. (2018). Economic analysis of sustainable water use: A review of worldwide research. Journal of Cleaner Production, 198, 1120-1132. https://doi. org/10.1016/j.jclepro.2018.07.066

4. Bakator, M., Đorđević, D., \& Ćoćkalo, D. (2019). Developing a model for improving business and competitiveness of domestic enterprises. Journal of Engineering Management and Competitiveness (JEMC), 9(2), 87-96.

5. Bešić, S., Ćoćkalo, D., Đorđević, D., \& Bogetić, S. (2014). The analysis of aspects of food industry competitivness in Serbia. Ekonomika poljoprivrede, 61(3), 647-659.

6. Caetano, I. (2017). Standardization and innovation management. Journal of innovation management, 5(2), 8-14. https://doi.org/10.24840/21830606_005.002_0003

7. Carrillo-Labella, R., Fort, F., \& Parras-Rosa, M. (2020). Motives, Barriers, and Expected Benefits of ISO 14001 in the Agri-Food Sector. Sustainability, 12(5), 1724. https://doi.org/10.3390/su12051724

8. Chen, H., Chen, Y., Liu, S., Yang, H., Chen, C., \& Chen, Y. (2019). Establishment the critical control point methodologies of seven major food processes in the catering industry to meet the core concepts of ISO 22000: 2018 based on the Taiwanese experience. Journal of Food Safety, 39(6), e12691. https://doi.org/10.1111/jfs.12691

9. Ćoćkalo D., Đorđević D., Kavalić M., \& Bešić C. (2019). Implementation of certification schemes in the Balkan agro-food sector. Ekonomika poljoprivrede, 66(1), 77-88.

10. Danas, (2020). Poljoprivredna i prehrambena industrija čuvaju pad BDP-a u Srbiji. Available at: https://www.danas.rs/ekonomija/poljoprivreda-i-prehrambenaindustrija-cuvaju-pad-bdp-a-u-srbiji/

11. De Clercq, M., Vats, A., \& Biel, A. (2018). Agriculture 4.0: The future of farming technology. Proceedings of the World Government Summit, Dubai, UAE, 11-13.

12. Domazet, I., Zubović, J., \& Lazić, M. (2018) Driving factors of Serbian competitiveness: Digital economy and ICT. Strategic Management, 23(1), 20-28. 
13. Đorđević, D., Ććkalo, D., \& Bogetić, S. (2016). The analysis of marketing concept implementation in domestic enterprises. Journal of engineering management and competitiveness (JEMC), 6(2), 120-128.

14. Đurić, D., Ristić, J., Đurić, D., \& Vujanić, I. (2017). Export of agricultural and food products in the function of economic growth of Republic of Serbia. Ekonomika poljoprivrede, 64(3).

15. FAO (2021). AQUASTAT. Available at: http://www.fao.org/aquastat/statistics/ query/index.html;jsessionid $=$ C43557B4E8BCD0F4D57FB0B7E7D53471

16. Gligorijević, Ž., Ćorović, E., \& Manasijević, A. (2020). Structural changes and economic growth of the Republic of Serbia: A contribution to the economic history of the second half of the 20th century. Ekonomika, 66(2), 37-48.

17. Ikram, M., Zhang, Q., Sroufe, R., \& Shah, S.Z.A. (2020). Towards a sustainable environment: The nexus between ISO 14001, renewable energy consumption, access to electricity, agriculture and $\mathrm{CO} 2$ emissions in SAARC countries. Sustainable Production and Consumption, 22, 218-230. https://doi.org/10.1016/j. spc.2020.03.011

18. ISO (2019). The ISO Survey. Available at: https://www.iso.org/the-iso-survey.html

19. Kim, N. (2021). The Impact of ISO22000 Standard Diffusion on Agricultural Exports. World Trade Review, 20(1), 40-55.

20. Klerkx, L., Jakku, E., \& Labarthe, P. (2019). A review of social science on digital agriculture, smart farming and agriculture 4.0: New contributions and a future research agenda. NJAS - Wageningen Journal of Life Sciences, 100315. https://doi. org/10.1016/j.njas.2019.10031

21. Mikhailushkin, P., Lubkova, E., Shilova, A., Zhuravlev, P., Karpenko, E., \& Nikiforov, S. (2018). Possibilities of agriculture competitiveness increasing. International Journal of Mechanical Engineering and Technology, 9(11), 1401-1412.

22. Miletić, V., Ćurčić, N., \& Simonović, Z. (2020). Standardizacija kvaliteta - faktor održive konkurentnosti preduzeća u Srbiji. Anali Ekonomskog fakulteta u Subotici (44), 99-114

23. Milojević, I., Mihajlović, M., Pantić, N. (2020). Collection and documentation of audit evidence. Oditor - časopis za menadžment, finansije i pravo, 6(2), 77-90. https://doi.org/10.5937/Oditor2002077M

24. Popović, B., \& Miletić, L. Z. (2016). Six sigma and six sigma system in the function of quality and profits increase. Journal of Engineering Management and Competitiveness (JEMC), 6(2), 129-142.

25. Republički Zavod za Statistiku - RZS (2018). Bruto domaći proizvod 2018. Available at: https://www.stat.gov.rs/sr-Latn/vesti/20191001-bruto-domaci-proizvod-2018

26. Republički Zavod za Statistiku - RZS (2019). Bruto domaći proizvod 2018. Available at: https://www.stat.gov.rs/sr-Latn/vesti/20201001-bruto-domaci-proizvod-2019 
27. Republički Zavod za Statistiku - RZS (2021). Baze podataka. Available at: https:// data.stat.gov.rs/?caller=SDDB

28. Rose, D.C., \& Chilvers, J. (2018). Agriculture 4.0: Broadening responsible innovation in an era of smart farming. Frontiers in Sustainable Food Systems, 2, 87. https://doi.org/10.3389/fsufs.2018.00087

29. Saidu, A., Clarkson, A.M., Adamu, S.H., Mohammed, M., \& Jibo, I. (2017). Application of ICT in agriculture: opportunities and challenges in developing countries. International Journal of Computer Science and Mathematical Theory, 3(1), 8-18.

30. Simonović, Z., \& Ćurčić, N. (2018). Some Aspects of Smart Technology Application in Agriculture of the Republic of Serbia. Sustainable Agriculture and Rural Development in Terms of the Republic of Serbia Strategic Goals Realization within the Danube Region : support programs for the improvement of agricultural and rural development. Institute of Agricultural Economics, Belgrade, 609-623.

31. Tomić, G., \& Radanov, P. (2020). Strategic Importance of Agriculture in the Republic of Serbia During the Pandemic Caused by the Corona Virus. MEFkon 2020 Innovation as an initiator of the development "Innovations in the function of development", 216.

32. Velasco-Muñoz, J.F., Aznar-Sánchez, J.A., Belmonte-Ureña, L.J., \& López-Serrano, M.J. (2018). Advances in Water Use Efficiency in Agriculture: A Bibliometric Analysis. Water, 10(4), 377. https://doi.org/10.3390/w10040377

33. WEF (2019). The Global Competitiveness Report 2019. Available at: http://www3. weforum.org/docs/WEF_TheGlobalCompetitivenessReport2019.pdf

34. Zhai, Z., Martínez, J.F., Beltran, V., \& Martínez, N.L. (2020). Decision support systems for agriculture 4.0: Survey and challenges. Computers and Electronics in Agriculture, 170, 105256. https://doi.org/10.1016/j.compag.2020.105256

35. Zhao, X., Castka, P., \& Searcy, C. (2020). ISO Standards: A Platform for Achieving Sustainable Development Goal 2. Sustainability, 12(22), 9332. https://doi. org/10.3390/su1222933 
